\title{
Model Spesifikasi Dinamis Permintaan Rokok: Rasionalkah Perokok Indonesia?
}

\author{
Budi Hidayat* Hasbullah Thabrany***
}

\begin{abstract}
Abstrak
Studi ini mengestimasi model spesifikasi dinamis permintaan (demand) rokok di Indonesia. Tujuannya adalah untuk menguji hipotesis kecanduan rasional perokok, dan menghitung elastisitas harga rokok jangka pendek dan jangka panjang. Analisis diaplikasikan pada data agregat individu yang dibentuk dari tiga tahapan survei panel IFLS selama tahun 1993-2000. Studi ini menjajagi sejumlah teknik ekonometrik dan memilih teknik tercocok atas dasar serangkaian uji statistik. Hasilnya menunjukkan bahwa rokok terbukti sebagai produk yang menimbulkan kecanduan (koefisien konsumsi masa lampau positif dan signifikan pada 1\%). Sedangkan koefisien negatif dan signifikan untuk konsumsi rokok masa depan menunjukan sifat kecanduan miopik, artinya para perokok bersifat tidak rasional. Studi ini juga menunjukkan permintaan rokok lebih sensitif terhadap perubahan harga untuk jangka panjang ketimbang untuk jangka pendek. Temuan bahwa perokok memiliki sifat kecanduan miopik mengharuskan pengambil kebijakan mendisain ulang strategi promosi kesehatan masyarakat tentang larangan merokok di Indonesia. Berbagi implikasi kebijakan temuan studi disajikan pula pada bagian akhir tulisan ini.
\end{abstract}

Kata kunci : Kecanduan rasional, sigaret, tembakau, elastisitas, data panel.

\section{Abstract}

This study estimates a dynamic model specification of demand for cigarette in Indonesia. The objectives are to test the rational addiction hypothesis of cigarettes demand, and to calculate price elasticity of cigarettes in the short-run and long-term. The data for this analysis were aggregate individual data from three-wave a panel surveys of the IFLS (Indonesian Family Life Survey) from 1993-2000. This study explores several econometric approaches, and selects the best fit of several statistical measures. The results indicate that cigarette indeed an addictive good (the lags consumption coefficients are a positive with $\mathrm{p}$-value $<1 \%$ ). Whilts a negative coefficient and significancy of future consumption indicate that smokers are myopic addicts, they are not rational. The study also confirms that the demand is more price sensitive for the long-run than the short-run. The finding of myopic addiction has pratical implications with which policy-makers should re-design current public health campaign against cigarette smoking in the country. Various policy implications of the research findings are also discussed in this article.

Key words : Rational addiction, cigarettes, tobacco, price elasticity, panel data.

*Pusat Kajian Ekonomi Kesehatan Universitas Indonesia, Gd. G Lt. 3 FKM UI, Kampus Baru UI Depok 16424 (e-mail: b_hidayat@hotmail.com)

**Pusat Kajian Ekonomi Kesehatan Universitas Indonesia, Gd. G Lt. 3 FKM UI, Kampus Baru UI Depok 16424 (e-mail: hasbullah.thabrany@yahoo.com) 
Studi tentang permintaan (demand) terhadap rokok dan/atau pengaruh harga rokok terhadap konsumsi rokok dapat dikelompokkan menurut model spesifikasi yang digunakan. Ada dua jenis model spesifikasi ekonometrik yang biasanya digunakan dalam studi ekonometrik. Pertama adalah model spesifikasi statis atau disebut model konvensional. Pada model ini peneliti mengesampingkan karakteristik dasar kecanduan tembakau. Model kedua dikenal dengan spesifikasi dinamis. Pada model spesifikasi dinamis, karakteristik kecanduan tembakau menjadi pertimbangan utama analisis. Aplikasi model dinamis dilakukan dengan meregresikan variabel terikat waktu sekarang ketika data dikumpulkan (konsumsi rokok pada $t-0$ ) dengan variabel terikat masa lalu (konsumsi rokok pada masa observasi sebelumnya $t$-1) dan/atau masa depan (konsumsi rokok pada masa observasi berikutnya $t+1$ ) plus sejumlah variabel independen lainnya. ${ }^{1}$

Kerangka analisis kajian ekonomi kecanduan terbagi menjadi tiga pendekatan, yakni: rasional tidak lengkap, miopik, dan rasional. ${ }^{2}$ Pendekatan kecanduan miopik dilakukan dengan meregresikan konsumsi sekarang $(t-0)$ dengan konsumsi masa lalu (variabel dependen $t$-1) dan sejumlah variabel independen lain. Sedangkan pada pendekatan kecanduan rasional (disingkat KR), variabel bebas yang digunakan bukan hanya variabel dependen $t-1$ tetapi juga $t+1$ beserta variabel independen lainnya. Kerangka analisis KR kini sudah menjadi pendekatan standar dan banyak digunakan dalam analisis berbagai produk yang mengakibatkan kecanduan seperti rokok dan alkohol, ${ }^{3}$ kokain, ${ }^{4}$ kopi, ${ }^{5}$ susu, ${ }^{6}$ dll.

Studi tentang permintaan rokok sudah banyak dilakukan di berbagai negara. Namun, sepanjang pengetahuan peneliti, studi yang menggunakan kerangka KR di negara berkembang belum pernah terpublikasi atau memang belum pernah dilakukan. Di Indonesia, analisis permintaan rokok pernah dilakukan hanya dengan model spesifikasi statis. ${ }^{7,8}$ Luaran studi semacam itu hanya menghasilkan elastisitas harga rokok jangka pendek, sedangkan elastisitas jangka panjang serta sifat kecanduan perokok tidak bisa dihasilkan. Padahal, kedua informasi elastisitas dan karakteristik kecanduan perokok penting, tidak hanya sebagai masukan pada penyusunan kebijakan tetapi juga sebagai bahan evaluasi pada programprogram anti merokok.

Studi ini dilakukan untuk mengisi kekosongan tersebut di atas. Tujuannya adalah untuk menguji hipotesis kecanduan rasional perokok dan menghitung elastisitas harga permintaan rokok jangka pendek dan jangka panjang. Untuk memunuhi tujuan ini, peneliti menggunakan model spesifikasi dinamis permintaan rokok dan mengadopsi kerangka analisis KR. Modelnya diaplikasikan dengan memanfaatkan ketersediaan data panel periode tahun 1993-2000. Studi ini menjajagi empat teknik ekonometrik dan mengkaji performa dari setiap teknik ana- lisis untuk memilih teknik tercocok.

Tulisan ini menaruh perhatian pada strategi pemilihan teknik ekonometrik untuk menganalisis model spesifikasi dinamis. Pembahasan diarahkan pada implikasi kebijakan temuan studi. Artikel ini diharapkan memberikan sumbangan, khususnya pengembangan metode penelitian di Indonesia. Hasil yang dipaparkan juga menambah fakta empiris mengenai ketersediaan laporan-laporan studi dengan pendekatan KR di negara maju. Survei yang dilakukan oleh Auld dan Grootendorst, ${ }^{6}$ menemukan bahwa luaran studi dengan pendekatan KR sering kurang memuaskan karena nilai pada masa berbeda (faktor diskon) tidak masuk akal, permintaan tidak stabil serta kecilnya elastisitas.

\section{Metode}

\section{Kerangka Analisis}

Teori KR dikembangkan pertama kali pada tahun 1988 oleh Becker dan Murphy. ${ }^{9}$ Kecanduan konsumen dalam memaksimalkan utilitas jangka panjang dirumuskan sebagai berikut: ${ }^{10}$

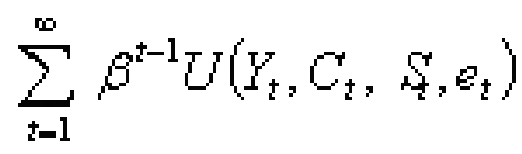

Rumus 1

dimana $\beta$ adalah faktor diskon, $e_{t}$ adalah pengaruh berbagai variabel siklus kehidupan yang tak terukur, dan $S_{t}$ adalah stok rokok waktu. $S_{t}$ dalam rumus 1 adalah $S_{t}=$ (1- $\delta) S_{t-1}+C_{t-1}$ dimana $\delta$ merupakan depresiasi cadangan atau stok rokok.

Seseorang akan memaksimalkan utilitas (1) tergantung persepsi dana (budget constraint) jangka panjang yang dimilikinya, yakni:

$$
W_{0}=\sum_{t=1}^{\infty} \beta^{t-1}\left(P_{t} C_{t}+Y_{t}\right)
$$

Rumus 2

dimana $W_{0}$ adalah nilai kesejahteraan orang tersebut saat ini, $P_{t}$ dan $C_{t}$ adalah harga dan konsumsi produk yang mengakibatkan kecanduan (adiktif) pada waktu $t$, dan $Y_{t}$ adalah konsumsi produk lain yang tidak menyebabkan kecanduan pada waktu $t$.

Deferensiasi formula (1) menghasilkan fungsi struktur permintaan produk adiktif pada waktu $t$ pada rumus 3, dimana $P_{t}$ adalah harga produk adiktif pada waktu $t ; \theta$ mengukur pengaruh konsumsi produk adiktif masa lampau serta mengukur pengaruh peningkatan konsumsi masa depan terhadap konsumsi produk adiktif saat ini. Semakin tinggi nilai $\theta$ semakin tinggi tingkat ketergatungan produk adiktif. 


\section{$C_{t}=\theta_{0}+\theta C_{t-1}+\beta C_{t+1}+\theta_{1} P_{t}+\theta_{2} e_{t}+\theta_{3} e_{t+1}$ \\ Rumus 3

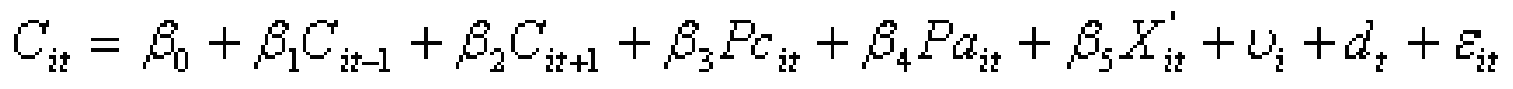 \\ Rumus 4}

\section{Pendekatan Ekonometrik}

Aplikasi empiris formula (3) dalam studi ini adalah rumus 4 , indek $i$ menunjukan individu nomor $i$, $t$ adalah waktu, $C$ adalah konsumsi rokok, $P c$ dan $P a$ masingmasing adalah harga rokok dan harga alkohol, $X^{\prime}$ adalah sejumlah variabel independen yang berpotensi mempengaruhi konsumsi rokok, $v_{i}$ adalah individual fixed effects, $d_{t}$ adalah time fixed effects untuk mengontrol berbagai perubahan tak terduga pada tingkat kesejahteraan, dan $\varepsilon_{i t}$ adalah error term. Sifat kecanduan perokok dikaji secara langsung dengan melihat hasil uji statistik koefisien $\beta_{2}$ pada formula (4) dan nilai faktor diskon. Jika koefisien $\beta_{2}$ bernilai positif dan signifikan maka artinya perokok memiliki kecanduan rasional. ${ }^{11}$

Untuk mengestimasi (4), pertama kami menggunakan analisis regresi biasa (ordinary least squares atau OLS). Asumsi OLS adalah nilai ekpektasi $\varepsilon_{i t}$ dengan kondisi sejumlah variabel independen akan sama dengan nol. Padahal, random error $\varepsilon_{i t}$ pada persamaan (4) mungkin berhubungan secara serial (serial correlation) dengan variabel lain karena data yang digunakan adalah data panel. ${ }^{1}$ Random error $\varepsilon_{i t}$ juga mempengaruhi utilitas konsumen pada setiap periode dan mempengaruhi konsumsi sepanjang periode tersebut melalui optimalisasi perilaku individu. Variabel $C_{t+1}$ dan $C_{t-1}$ sebagai determinan $\mathrm{C}_{t-0}$ pada model spesifikasi dinamis berpeluang menimbulkan seleksi bias (pada terminologi ekonometrik dikenal sebagai endogen). Jika satu saja dari ketiga masalah tersebut terjadi maka estimasi (4) dengan OLS akan menghasilkan nilai $\varepsilon_{i t}$ tidak sama dengan nol.

Oleh karena itu, untuk mengoreksi kemungkinan endogenitas $C_{t-1}$ and $C_{t+1}$ serta mengakomodasi perilaku $\varepsilon_{i t}$ pada persamaan (4), studi ini menggunakan pendekatan variabel instrumental (VI), yakni metoda: two-stage least squares (2SLS), generalized method of moment (GMM) dan System-GMM. Estimator 2SLS akan menghasilkan standard errors tidak konsisten apabila terdapat heteroskesdasitas. Kelemahan ini dapat diakomodir dengan GMM. Windmeijer dan Santos-Silva, ${ }^{11}$ menyebutkan bahwa GMM akan menghasilkan parameter estimasi yang tetap konsisten meskipun ada heteroskesdasitas. Analisis GMM juga akan menghasilkan estimasi parameter/koefisien asimptot yang efisien walaupun $\varepsilon_{i t}$ berhu- bungan secara serial. Penggunaan System-GMM bukan hanya untuk mengoreksi ketiga masalah tersebut di atas tetapi juga untuk mengoreksi kemungkinan adanya kesalahan pengukuran variabel serta berbagai faktor individu yang tidak diketahui peneliti (unobservable heterogeneity). 12

\section{Uji Statistik}

Untuk mengevaluasi model keseluruhan serta untuk memilih teknik tercocok, studi ini menggunakan sejumlah uji statistik. Pertama adalah uji eksogenitas variabel $C_{t-1}$ dan $C_{t+1}$. Uji ini dilakukan dengan mengaplikasikan spesifikasi Hausman. Kedua adalah uji Pagan dan Hall's. ${ }^{13}$ Uji ini digunakan untuk mendeteksi heteroskesdasitas dan pada penelitian ini dimanfaatkan pula untuk memilih 2SLS atau GMM. Ketiga adalah uji variabel instrumental. Uji ini dilakukan untuk mengevaluasi kemungkinan adanya bias parameter estimasi yang disebabkan oleh tidak tepatnya variabel instrumen (selanjutnya disebut variabel z). Konsistensi parameter estimasi yang dihasilkan oleh estimasi VI (khususnya 2SLS dan GMM) tergantung pada ketersediaan variabel z. Variabel z harus memenuhi sejumlah syarat, yaitu berhubungan dengan variabel endogen, valid, dan orthogonal dengan $\varepsilon_{i t}$. Apabila satu saja dari syaratsyarat tersebut tidak terpenuhi hasil estimasi VI kurang tepat.

Uji statistik yang digunakan untuk mendeteksi persyaratan $\mathrm{z}$ terdiri atas tiga. Pertama adalah uji korelasi antara $\mathrm{z}$ dengan variabel endogen. Ini dilakukan dengan mereduksi $C_{t-1}$ dan $C_{t+1}$ dari formula (4) dan memperlakukan kedua variabel tersebut sebagai variabel dependen untuk kemudian dianalisis dengan OLS. Variabel independen yang digunakan sebagai determinan $C_{t-1}$ dan $C_{t+1}$ sama dengan formula (4) ditambah sejumlah variabel z. Hubungan variable $\mathrm{z}$ dengan $C_{t-1}$ dan $C_{t+1}$ lalu dikaji dengan mengevaluasi $R^{2}$ serta uji-F. ${ }^{14}$ Mengingat ada dua variabel yang kemungkinan bersifat endogen, kedua $R^{2}$ dan uji-F diduga belum bisa mendeteksi keterkaitan z dengan $C_{t-1}$ dan $C_{t+1}$. Hal ini memotivasi kami untuk mengadopsi nilai Shea partial- $R^{2} .15$

Kedua adalah uji validitas z. Uji ini dilakukan dengan restriksi identifikasi, yakni dengan uji statistik Hansen-J 
Tabel 1. Definisi Variabel Statistik Deskriptif

\begin{tabular}{|c|c|c|c|c|c|c|c|c|c|}
\hline \multirow[t]{2}{*}{ Variabel } & \multirow[t]{2}{*}{ Definisi } & \multicolumn{2}{|c|}{ IFLS 1993} & \multicolumn{2}{|c|}{ IFLS 1997} & \multicolumn{2}{|c|}{ IFLS 2000} & \multicolumn{2}{|c|}{ Pooled } \\
\hline & & Mean & $\overline{\text { SD }}$ & Mean & $\overline{\text { SD }}$ & Mean & $\overline{\text { SD }}$ & Mean & $\overline{\mathrm{SD}}$ \\
\hline$C_{t 0}$ & Konsumsi rokok sekarang $(\ln )$ & 2.162 & 0.789 & 2.233 & 0.745 & 2.210 & 0.722 & 2.207 & 0.746 \\
\hline$C_{t-1}$ & Konsumsi rokok lalu $(\ln )$ & n.a & n.a & 2.156 & 0.776 & 2.234 & 0.748 & 2.203 & 0.760 \\
\hline$C_{t+1}^{t-1}$ & Konsumsi rokok depan $(\ln )$ & 2.242 & 0.739 & 2.218 & 0.717 & n.a & n.a & 2.230 & 0.727 \\
\hline$P c_{t O}$ & Harga rokok sekarang $(\ln )$ & 4.169 & 0.665 & 4.407 & 0.245 & 5.374 & 0.168 & 4.623 & 0.701 \\
\hline$P c_{t-1}$ & Harga rokok lalu $(\ln )$ & n.a & n.a & 4.156 & 0.669 & 4.405 & 0.245 & 4.280 & 0.520 \\
\hline$P c_{t+1}$ & Harga rokok depan $(\ln )$ & 4.403 & 0.246 & 5.369 & 0.166 & n.a & n.a & 4.882 & 0.526 \\
\hline$P a_{t O}$ & Harga alkohol sekarang $(\ln )$ & 7.673 & 1.129 & 8.374 & 1.076 & 9.331 & 1.024 & 8.612 & 1.263 \\
\hline Pendapatan & Pendapatan perkapita perbulan $(\ln )$ & 10.629 & 0.863 & 11.079 & 0.812 & 11.891 & 0.848 & 11.156 & 1.004 \\
\hline Bekerja & 1 bekerja, 0 lainnya & 0.611 & 0.488 & 0.549 & 0.498 & 0.592 & 0.491 & 0.582 & 0.493 \\
\hline Tembok & 1 rumah bertembok, 0 lainnya & 0.519 & 0.500 & 0.610 & 0.488 & 0.660 & 0.474 & 0.588 & 0.492 \\
\hline Lantai & 1 lantai rumah permanen, 0 lainnya & 0.191 & 0.393 & 0.149 & 0.356 & 0.112 & 0.316 & 0.155 & 0.362 \\
\hline Rumah & 1 memiliki rumah, 0 lainnya & 0.794 & 0.404 & 0.823 & 0.382 & 0.805 & 0.396 & 0.805 & 0.396 \\
\hline Islam & 1 beragama Islam, 0 lainnya & 0.858 & 0.349 & 0.877 & 0.328 & 0.882 & 0.322 & 0.871 & 0.335 \\
\hline
\end{tabular}

Tabel 2. Statistik Deskriptif Perilaku Merokok di Indonesia

\begin{tabular}{|c|c|c|c|c|c|c|c|c|c|c|c|c|}
\hline & \multicolumn{3}{|c|}{ IFLS 1993} & \multicolumn{3}{|c|}{ IFLS 1997} & \multicolumn{3}{|c|}{ IFLS 2000} & \multicolumn{3}{|c|}{ Pooled } \\
\hline & Wanita & Pria & Total & Wanita & Pria & Total & Wanita & Pria & Total & Wanita & Pria & Total \\
\hline Pernah merokok & 0.12 & 0.77 & 0.42 & 0.07 & 0.69 & 0.35 & 0.06 & 0.70 & 0.36 & 0.08 & 0.71 & 0.37 \\
\hline Masih merokok & 0.10 & 0.70 & 0.38 & 0.06 & 0.64 & 0.33 & 0.05 & 0.65 & 0.34 & 0.07 & 0.66 & 0.34 \\
\hline Berhenti merokok & 0.02 & 0.07 & 0.04 & 0.01 & 0.05 & 0.03 & 0.01 & 0.05 & 0.03 & 0.01 & 0.06 & 0.03 \\
\hline Sigaret & 0.38 & 0.81 & 0.74 & 0.41 & 0.90 & 0.85 & 0.48 & 0.93 & 0.89 & 0.42 & 0.89 & 0.84 \\
\hline Melinting & 0.12 & 0.28 & 0.26 & 0.07 & 0.17 & 0.16 & 0.06 & 0.12 & 0.11 & 0.09 & 0.18 & 0.17 \\
\hline Mengunyah tembakau & 0.55 & 0.02 & 0.10 & 0.55 & 0.01 & 0.07 & 0.49 & 0.01 & 0.05 & 0.53 & 0.01 & 0.07 \\
\hline Menggunakan pipa & 0.01 & 0.01 & 0.01 & 0.00 & 0.01 & 0.01 & 0.00 & 0.00 & 0.00 & 0.00 & 0.00 & 0.00 \\
\hline Usia mulai merokok (yrs) & 27.2 & 21.5 & 22.3 & 27.7 & 20.5 & 21.4 & 27.3 & 20.4 & 21.3 & 27.4 & 20.8 & 21.6 \\
\hline \# konsumsi sigaret per hari & 7.4 & 11.3 & 11.0 & 7.9 & 12.6 & 12.3 & 7.0 & 12.2 & 11.8 & 7.4 & 12.1 & 11.7 \\
\hline
\end{tabular}

(untuk GMM), serta uji Sargan dan Basman (untuk 2SLS). Hipotesis nol uji statistik tersebut adalah bahwa tidak dimasukannya variabel $\mathrm{z}$ adalah valid (tidak berhubungan dengan $\varepsilon_{i t}$ ). Ketiga adalah uji ortogonalitas variabel z yang dilakukan dengan uji $C$-statistik. ${ }^{16}$

\section{Data dan Variabel}

Penelitian ini menggunakan data pooled individu yang dibentuk dari 3 tahapan survei panel IFLS (Indonesian Family Life Survey). Data pertama IFLS dikumpulkan tahun 1993 (IFLS1), kedua tahun 1997 (IFLS2), dan ketiga tahun 2000 (IFLS3). Pelaksanaan surveinya dikoordinir oleh RAND Corporation dari Amerika, bekerja sama dengan peneliti Indonesia serta sejumlah lembaga donor internasional. Sebanyak 7.730 rumah tangga terpilih sebagai sampel untuk memenuhi kuota 7.000 sampel rumah tangga. Dalam IFLS1 berhasil dikumpulkan data dari 7.224 rumah tangga. Pada tahun 1997, sebanyak 6.751 rumah tangga yang pernah disurvei tahun 1993 berhasil disurvei kembali (93,5\% rumah tangga
IFLS1). Sebesar 95,3\% rumah tangga IFLS1 berhasil diwawancarai lagi pada IFLS3. Informasi lengkap tentang IFLS dapat ditemui pada laporan yang ditulis oleh Frankenberg and Karoly, ${ }^{17}$ Frankenberg dan Thomas, ${ }^{18}$ dan Straus, ${ }^{19}$ masing-masing untuk IFLS1, IFLS2, dan IFLS3. Laporan-laporan tersebut dapat diakses di www.rand.org.

Data IFLS cocok dengan spesifikasi dinamis yang digunakan untuk studi ini. Data individu tercatat secara rinci dan diperoleh atas jawaban dari sekitar 22.000 responden IFLS1, 33.000 responden IFLS2, dan 39.000 responden IFLS3. Kuesioner IFLS mengajukan sejumlah pertanyaan tentang perilaku merokok orang dewasa (diatas 15 tahun).

Tabel 1 menyajikan daftar variabel yang digunakan. Variabel dependen adalah jumlah konsumsi rokok per hari pada waktu IFLS2 (dianggap waktu sekarang). Sesuai model spesifikasi dinamis (4), variabel dependen yang diperlakukan sebagai independen adalah jumlah konsumsi rokok masa lalu $\left(C_{i t-1}\right)$ dan masa mendatang 
Table 3. Ringkasan Uji Statistik

\begin{tabular}{llll}
\hline & \multicolumn{2}{c}{ Nilai Statistik } & P-val \\
\hline Uji eksogenitas: & & & \\
Konsumsi masa lampau dan masa depan & & & \\
Wu-Hausman & $\mathrm{F}(2,1775):$ & 3.5 & 0.031 \\
Durbin-Wu-Hausman & $\mathrm{Chi}^{2}(2):$ & 6.9 & 0.031 \\
Uji heteroskedastisitas: & & & \\
Pagan-Hall general test & $\mathrm{Chi}^{2}(11):$ & 15.5 & 0.159 \\
Pagan-Hall test w/assumed normality & $\mathrm{Chi}^{2}(11):$ & 34.1 & 0.000 \\
White/Koenker n*R2 test & $\mathrm{Chi}^{2}(11):$ & 16.4 & 0.128 \\
Breusch-Pagan/Godfrey/Cook-Weisberg & $\mathrm{Chi}^{2}(11):$ & 36.9 & 0.000 \\
Uji restriksi over-identifikasi: & & & \\
Sargan N*R-sq (2SLS) & $\mathrm{Chi}^{2}(6):$ & 8.7 & 0.192 \\
Basmann test (2SLS) & $\mathrm{Chi}^{2}(6):$ & 8.7 & 0.193 \\
Hansen J (GMM) & $\mathrm{Chi}^{2}(6):$ & 8.0 & 0.237 \\
Hansen J (GMM-system) & $\mathrm{Chi}^{2}(33):$ & 20.1 & 0.962 \\
\hline
\end{tabular}

Tabel 4. Hasil Estimasi Regresi OLS Variabel Endogen

\begin{tabular}{|c|c|c|c|c|}
\hline & \multicolumn{2}{|c|}{ Konsumsi masa lalu $\left(C_{t-1}\right)$} & \multicolumn{2}{|c|}{ Konsumsi masa depan $\left(C_{t+1}\right)$} \\
\hline & Coef. & SE & Coef. & SE \\
\hline$P c_{t O}$ & $-0.364^{* * *}$ & 0.075 & $-0.232^{* * *}$ & 0.069 \\
\hline $\mathrm{Pa}_{\text {tO }}$ & $0.252^{* * *}$ & 0.020 & $0.227^{* *}$ & 0.018 \\
\hline Pendapatan & -0.011 & 0.023 & 0.018 & 0.021 \\
\hline$P c_{t-1}$ & $0.055^{*}$ & 0.027 & -0.016 & 0.025 \\
\hline$P c_{t+1}$ & -0.081 & 0.118 & $-0.301^{* * *}$ & 0.108 \\
\hline Bekerja $t+1$ & -0.063 & 0.047 & $0.153^{* * *}$ & 0.043 \\
\hline Bekerja $t-1$ & $0.150^{* * *}$ & 0.053 & $0.085^{* * * *}$ & 0.049 \\
\hline Tembok rumah & $-0.121_{* *}^{* *}$ & 0.034 & -0.041 & 0.031 \\
\hline Lantai rumah permanen & $-0.239^{* *}$ & 0.049 & $-0.079^{* * * *}$ & 0.045 \\
\hline Kepemilikan rumah & -0.050 & 0.039 & -0.038 & 0.035 \\
\hline Islam & $-0.193^{* * *}$ & 0.053 & $-0.137^{* * *}$ & 0.048 \\
\hline Konstanta & $2.261^{* *}$ & 0.550 & $2.925^{* *}$ & 0.504 \\
\hline Jumlah observasi & 1783 & & 1783 & \\
\hline $\mathrm{R}^{2}$ & 0.133 & & 0.124 & \\
\hline Shea Partial R² & 0.031 & & 0.021 & \\
\hline Partial R2 & 0.036 & & 0.024 & \\
\hline Uji-F semua instrumen & $24.77^{* *}$ & & $22.69 * *$ & \\
\hline Uji-F hanya instrumen $z$ & $8.22 * *$ & & $5.43^{* *}$ & \\
\hline
\end{tabular}

*signifikan pada 5\%; ${ }^{* *}$ signifikan pada $1 \%$; ${ }^{* * * *}$ signifikan pada $10 \%$; SE adalah robust standard errors

$\left(C_{i t+1}\right)$. Variabel ini mengukur pengaruh konsumsi rokok masa lampau dan masa depan terhadap utilitas marjinal konsumsi rokok sekarang. Harga rokok $\left(P c_{i t}\right)$ dan alkohol $\left(P a_{i t}\right)$ dimasukan sebagai variabel independen. Variabel independen lainnya $\left(X_{i t}^{\prime}\right)$ adalah pendapatan per kapita (diproksi dengan pengeluaran per kapita).

Variabel harga dan pendapatan disajikan dalam nilai riil dengan cara mendeflasi nilai rupiah dengan indek harga konsumen tahun 1997. Seluruh variabel (dependen dan independen) dikonversi ke dalam bentuk logaritmik. Tujuannya adalah untuk menormalkan distribusi data serta untuk memudahkan interpretasi koefisien. Hasil koefisien estimasi dalam model log-log secara langsung mencerminkan nilai elastisitas.

Variabel harga rokok masa lalu dan masa depan di- gunakan sebagai variabel instrumen $\mathrm{z}$ untuk konsumsi rokok masa lalu dan masa depan. Variabel yang mencerminkan kejadian penting dalam siklus kehidupan seseorang (misal pekerjaan) diduga mempengaruhi utilitas sehingga secara parsial akan menentukan $\varepsilon_{i t}$. Oleh karena itu, kami masukan pula status pekerjaan pada masa sebelumnya dan masa setelah itu sebagai instrumen $z$. Variabel z lainnya terdiri atas sejumlah variabel dummy, yaitu: jenis tembok $(1 / 0)$, jenis lantai $(1 / 0)$, kepemilikan rumah (1/0) dan beragama Islam (1/0).

\section{Hasil}

\section{Statistik Deskriptif}

Tampak pada Tabel 2 bahwa tidak kurang dari 77\% pria dewasa melaporkan pernah merokok pada tahun 
Tabel 5. Hasil Estimasi Kecanduan Rasional Perokok Model Perbandingan

\begin{tabular}{lllll}
\hline & \multicolumn{4}{c}{ Model Estimasi } \\
\cline { 2 - 5 } & OLS & 2SLS & GMM & System-GMM \\
\hline Konsumsi masa lalu $\left(C_{t-1}\right)$ & $0.244^{* * *}$ & $0.520^{* * *}$ & $0.521^{* * *}$ & $0.846^{* * *}$ \\
& {$[0.021]$} & {$[0.113]$} & {$[0.112]$} & {$[0.130]$} \\
Konsumsi masa depan $\left(C_{t+1}\right)$ & $0.318^{* * *}$ & 0.133 & 0.119 & $-0.749^{* * *}$ \\
& {$[0.027]$} & {$[0.152]$} & {$[0.145]^{* * * *}$} & {$[0.078]^{* * *}$} \\
Harga rokok $\left(P c_{t 0}\right)$ & $-0.154^{* * *}$ & $-0.118^{* * *}$ & $-0.129^{* * *}$ & $-0.358^{* *}$ \\
& {$[0.045]$} & {$[0.070]$} & {$[0.066]$} & {$[0.084]$} \\
Harga Alkohol $\left(\mathrm{Pa}_{t 0}\right)$ & $0.182^{* * *}$ & $0.152^{* * *}$ & $0.157^{* * *}$ & $0.253^{* * *}$ \\
& {$[0.019]$} & {$[0.035]$} & {$[0.035]$} & {$[0.060]$} \\
Pendapatan per kapita & -0.021 & -0.016 & -0.015 & 0.023 \\
& {$[0.018]$} & {$[0.018]$} & {$[0.018]$} & {$[0.056]$} \\
Konstanta & $0.469^{* *}$ & 0.333 & 0.36 & $1.455^{* * *}$ \\
& {$[0.226]$} & {$[0.351]$} & {$[0.354]$} & {$[0.768]$} \\
Jumlah observasi & & & & \\
$\mathrm{R}^{2}$ & 1790 & 1783 & 1783 & 1783 \\
Uji-F & 0.41 & 0.33 & 0.33 & \\
Jumlah total instrumen & $181.45^{* * *}$ & $104.72^{* * *}$ & $81.72^{* * *}$ & $27.63^{* * *}$ \\
Jumlah instrumen $(\mathrm{z})$ & & 12 & 12 & 39 \\
Elastisitas jangka pendek & 8 & 8 & & \\
Elastisitas jangka pendek & -0.154 & -0.118 & -0.129 & -0.358 \\
Faktor diskon & -0.352 & -0.340 & -0.358 & -0.396 \\
Diskon rate & 1.303 & 0.256 & 0.228 & -0.885 \\
& -0.233 & 2.910 & 3.378 & -2.130 \\
\hline
\end{tabular}

Catatan: Lihat formula (4): Nilai elastisitas jangka pendek adalah nilai dari koefisien estimasi pada variabel harga rokok, $\beta_{3}$; nilai elastisitas jangka panjang dihitung dengan rumus 5 ; nilai diskon fakor adalah $\beta_{2} / \beta_{1}$, sedangkan angka diskon dihitung dengan rumus $\beta_{1} / \beta_{2}-1$.

1993. Angka ini turun menjadi 69\% pada tahun 1997 dan naik kembali menjadi $70 \%$ pada tahun 2000 . Prevalensi perokok sekarang berbeda tipis dengan prevalensi pernah merokok. Tidak heran jika angka berhenti merokok sangat kecil, yakni kurang dari $4 \%$. Sebagian besar perokok pria $(>90 \%)$ menghisap sigaret. Dalam IFLS 2000 93\% perokok pria memilih sigaret. Hanya 12\% wanita dewasa pernah merokok pada 1993. Angka ini turun menjadi 7\% pada tahun 1997 dan 6\% pada tahun 2000. Berbeda dengan pria, wanita yang mengunyah tembakau 55\% lebih banyak dibandingkan pria yang mengunyah tembakau.

Jumlah konsumsi sigaret rata-ratanya mencapai 12 batang per hari. Jumlah konsumsi rokok di ketiga dataset yang dianalisis tidak menunjukkan perbedaan yang signifikan. Rerata rokok yang dihisap perokok pria mencapai $30-40 \%$ lebih banyak ketimbang rerata rokok yang dihisap perempuan.

\section{Pemilihan Tehnik Ekonometrik}

Uji spesifikasi Hausman menolak hipotesis nol eksogenitas pada tingkat 5\% (lihat Tabel 3). Ini berarti variabel $C_{t-1}$ dan $C_{t+1}$ terbukti bersifat endogen. Temuan ini menggiring kami untuk meninggalkan OLS. Selanjutnya, uji Pagan-Hall dengan asumsi normalitas serta uji
Breusch-Pagan/Godfrey/Cook-Weisberg menolak hipotesis nol pada tingkat $1 \%$. Temuan ini memberikan cukup bukti untuk memilih GMM sebagai kandidat estimator ketimbang 2SLS.

Pemilihan GMM atau System-GMM dilakukan dengan mempertimbangkan seluruh hasil uji variabel instrumental. Uji validitas instrumen Hansen J, Basmann dan Sargan menerima hipotesis nol yang menyatakan tidak ada overidentifikasi. Dengan demikian variabel z valid dan model terspesifikasi dengan benar. Sayangnya, uji C-statistik tidak bisa menerima hipotesis nol yang berarti persyaratan ortogonalitas z tidak terpenuhi.

Tabel 4 menyajikan hasil regresi OLS variabel endogen $C_{t-1}$ dan $C_{t+1}$. Nilai $R^{2}$ untuk $C_{t-1}$ dan $C_{t+1}$ masingmasing adalah $13 \%$ dan $12 \%$. Estimasi model yang menghasilkan nilai Partial $R^{2}$ tinggi, namun Shea Partial $R^{2}$ rendah mencerminkan lemahnya hubungan $\mathrm{z}$ dengan variabel endogen. Kesenjangan (gap) antara Partial $R^{2}$ dengan Shea Partial $R^{2}$ dalam studi ini relatif kecil sehingga dapat diartikan modelnya teridentifikasi baik.

Keterkaitan z dengan $C_{t-1}$ dan $C_{t+1}$ dikaji pula dengan uji- $F$. Meskipun hasil uji- $F$ signifikan pada tingkat 1 persen, yang berarti $z$ berhubungan dengan variabel endogen, besaran nilai uji-F mengundang pertanyaan. Acuan dasar untuk satu variabel endogen diajukan oleh 


\section{$\partial E\left(\operatorname{Ln} C_{i t}\right) / \partial E\left(\operatorname{Ln} P_{i t}\right)=\hat{\beta}_{3} /\left(1-\hat{\beta}_{1}-\hat{\beta}_{2}\right)$}

Rumus 5

Bound, ${ }^{14}$ yang menyebutkan bahwa, uji-F kurang dari 10 merupakan indikasi lemahnya hubungan $\mathrm{z}$ dengan variabel endogen. Studi ini menemukan nilai uji-F berada dibawah angka 10 (yaitu 8,2 untuk konsumsi masa lalu dan 5,4 untuk konsumsi masa depan), padahal ada dua variabel endogen. Tidak terpenuhinya persyaratan ortogonalitas dan keterkaitan variabel z mendorong kami untuk tidak memilih GMM melainkan System-GMM.

\section{Model Estimasi}

Meskipun System-GMM yang dipilih, untuk perbandingan, Tabel 5 menyajikan juga hasil estimasi yang dilakukan dengan tiga estimator lainnnya. Baris akhir Tabel 5 menyajikan hasil perhitungan elastisitas harga rokok, diskon faktor serta diskon rate. Elastisitas jangka pendek diperoleh langsung dari besaran koefisien estimasi harga rokok. Sedangkan untuk elastisitas jangka panjang dihitung dengan Rumus 5.7 Rasio koefisien estimasi konsumsi rokok masa depan terhadap konsumsi rokok masa lalu, $\beta_{2} / \beta_{1}$ merupakan nilai diskon faktor. Nilai koefisien konsumsi tersebut digunakan juga untuk menghitung angka diskon dengan formula $\beta_{1} / \beta_{2}-1$.

Tampak pada Tabel 5 bahwa semua parameter estimasi yang diperoleh dengan System-GMM, kecuali pendapatan per kapita, signifikan pada tingkat $1 \%$. Koefisien estimasi konsumsi rokok masa lalu positif, sedangkan konsumsi rokok masa depan bernilai negatif. Nilai elastisitas jangka pendek dan panjang secara berurutan adalah $-0,38$ dan $-0,39$ (signifikan pada tingkat 1 $\%)$.

\section{Pembahasan \\ Pendekatan Analisis}

Studi ini menganalisis model spesifikasi dinamis permintaan rokok dengan OLS, 2SLS, GMM, dan SystemGMM. Estimator OLS menghasilkan koefisien parameter estimasi dan standar error yang konsisten jika dan hanya jika seluruh variabel bebas bersifat eksogen, dan random error-nya homoskedastik serta tidak berhubungan serial. ${ }^{1}$ Meskipun mampu mengoreksi eksogenitas variabel independen, estimator 2SLS, GMM, dan System-GMM kurang efisien ketimbang OLS. Koreksi seleksi bias dengan ketiga estimator tersebut jika masalah seleksi bias tidak terbukti justru menghasilkan nilai standard errors yang tinggi sehingga mempengaruhi ketepatan uji statistik. ${ }^{17}$ Jadi, ada trade-off antara berkurangnya ketepatan estimasi dan hasil parameter estimasi yang bias. Pemilihan metode estimasi merupakan proses yang rumit untuk menghasilkan estimasi yang tercocok. Hal ini penting untuk ketepatan perumusan kebijakan berdasarkan fakta hubungan statistik yang akurat.

Langkah awal pemilihan metode estimasi dilakukan dengan mengkaji kemungkinan seleksi bias, akibat adanya variabel dependen masa lalu dan masa lampau sebagai variabel independen dalam model spesifikasi dinamis. Hasil uji eksogenitas dalam studi ini membuktikan adanya seleksi bias tersebut. Banyak peneliti melakukan regresi biasa (OLS) yang mengakibatkan estimasi formula (4) menghasilkan nilai random-error yang tidak sama dengan nol, sehingga koefisien yang diperoleh tidak valid. ${ }^{1}$

Kajian literatur menemukan bahwa 2SLS sudah digunakan secara luas untuk pembuktian hipotesis ketergantungan rasional. ${ }^{4-7,11}$ Salah satu manfaat metoda ini adalah untuk mengoreksi seleksi bias variabel independen. Namun demikian, 2SLS tidak dipilih dalam studi ini karena ada dua alasan pokok. Pertama, adanya hetersoskedastisitas (atau non-konstan varian) pada sistem regresi. Hal ini mengakibatkan standar-error yang dihasilkan oleh 2SLS menjadi tidak konsisten sehingga uji statistiknya juga menjadi tidak valid. Kedua, tidak semua uji variabel instrumental memenuhi kriteria terpilihnya $\mathrm{z}$ sebagai instrumen yang baik. Hal ini dapat dilihat dari kecilnya nilai uji-F $(<10)$ pada regresi reduksi persaman (4), serta tidak ortogonalnya $\mathrm{z}$ dengan random-error. Alasan yang kedua ini memberikan juga sinyal lampu merah pada penggunaan GMM. Atas dasar pertimbangan diatas, studi ini menggunakan System-GMM sebagai estimator tercocok untuk mengestimasi model spesifikasi dinamis permintaan rokok.

Estimasi formula (4) dengan System-GMM menghasilkan jumlah variabel instrumen menjadi 39. Bandingkan dengan hasil estimasi yang dilakukan dengan 2SLS dan GMM yang hanya menghasilan 12 variabel instrumen (lihat Tabel 5). Sementara itu, Baltagi and Grifin, ${ }^{3}$ menjelaskan bahwa estimator yang memberikan terlalu banyak restriksi over identifikasi instrumen memberikan performa buruk. Untuk mengurangi bias yang disebabkan oleh terlalu banyaknya ristriksi overidentifikasi, studi ini menggunakan metode yang dikembangkan oleh David Roodman, ${ }^{20}$ dan menerapkan modul "xtabond2" pada STATA.

\section{Sifat Kecanduan Perokok}

Deteksi produk-produk yang mengakibatkan kecanduan dalam model spesifikasi dinamis dapat dibuktikan 
dengan mengkaji koefisien estimasi konsumsi produk tersebut pada masa lalu. Hasil analisis yang menunjukkan nilai positif dan signifikan koefisien estimasi konsumsi rokok masa lalu membuktikan bahwa rokok memang merupakan produk yang mengakibatkan kecanduan. ${ }^{11}$ Temuan ini dibuktikan secara empiris tidak hanya dari hasil estimasi yang dilakukan oleh System-GMM tetapi juga oleh ketiga uji statistik lainnya.

System-GMM menghasilkan koefisien estimasi bernilai negatif pada variabel konsumsi masa depan. Hal ini mengakibatkan perhitungan angka diskon (yakni $\beta_{2} / \beta_{1}$ ) menjadi tidak masuk akal. Negatif dan signifikansinya koefisien estimasi konsumsi masa depan, serta tidak masuk akalnya nilai diskon fakor merupakan indikasi kuat untuk menolak hipotesis kecanduan rasional.4,11 Temuan ini membuktikan bahwa perokok tidak memikirkan implikasi negatif dari perilakunya. Artinya, perokok Indonesia memiliki sifat kecanduan miopik sehingga tidak peduli akan risiko rokok terhadap kesehatan, seperti menjadi sakit-sakitan, terkena serangan jantung, bahkan sampai meninggal pada usia muda. Mereka juga tidak memikirkan dampak negatif pada aspek ekonomi, seperti relatif turunnya tingkat pendapatan karena digunakan untuk belanja rokok dan/atau untuk biaya sakit yang ditimbulkan oleh perilaku merokok, turunnya pendapatan karena menjadi sakit-sakitan sehingga tidak mampu bekerja, dll. Jangan heran, jika Majlis Ulama Jawa Tengah menolak fatwa hukum merokok haram. Hal tersebut merupakan implikasi miopik.

Ada dua kemungkinan yang saling berinteraksi yang menyebabkan sifat kecanduan perokok Indonesia tidak rasional. Pertama, perokok kurang mencerna dengan baik tentang dampak negatif rokok. Mereka menempatkan manfaat subyektif dan maya dari kegiatan merokok seperti perasaan nikmat dan perasaan terbebas dari tekanan lebih tinggi ketimbang dampak negatif rokok. Meski informasi tentang bahaya rokok tertulis dalam bungkus rokok, hal itu tidak mengubah perilaku mereka. Temuan studi ini merefleksikan bahwa perokok tidak memproses informasi peringatan bahaya rokok dengan benar. Perokok tidak sepenuhnya sadar akan risiko penyakit dan kematian dini akibat pilihan mereka itu. Ini berarti efektivitas pesan anti merokok tidak memadai.

Kedua, perokok seringkali terpapar oleh banyaknya pesan-pesan yang menyenangkan tentang rokok, dan pesan tersebut mengaburkan pemikiran atau pandangan perokok terhadap berbagai risiko rokok. Sebuah iklan produk rokok tertentu menyampaikan pesan "Bukan Sembarang Pria" dengan tulisan besar, diikuti model lelaki yang kekar, serta setting yang menarik. Iklan tersebut berpeluang besar untuk mengaburkan pesan-pesan efek negatif rokok. Perang dingin antara sejumlah produsen rokok yang begitu gencar dengan iklan-iklan di TV,
Baliho, dll (misal: "Bukan Basa Basi", "Mana Janjimu", dll) juga semakin menenggelamkan pesan-pesan promosi kesehatan. Sementara itu, pesan anti merokok (yakni "merokok dapat menyebabkan kanker, serangan jantung, impotensi dan gangguan kehamilan dan janin") yang tertulis disetiap bungkus rokok dan pada iklan-iklan rokok hanya dikemas dalam ukuran huruf yang relatif kecil ketimbang produk rokok maupun pesan yang disampaikan oleh produk rokok.

\section{Elastisitas}

Analisis statististik menunjukan bahwa harga rokok berhubungan negatif dengan konsumsi. Temuan ini selaras dengan hukum permintaan yang menyatakan bahwa semakin tinggi harga semakin rendah jumlah permintaan. Elastisitas harga rokok jangka panjang $(-0,39)$ lebih tinggi ketimbang elastisitas jangka pendek $(-0,35)$. Nilai elastisitas studi ini memang kecil, namun tidak berbeda jauh dengan elastisitas studi terdahulu (yakni -0,34) dengan sumber data berbeda. ${ }^{9}$ Elastisitas harga rokok temuan studi ini juga sepadan dengan elastisitas yang diperoleh dari berbagai studi yang dilakukan di negara berpenghasilan tinggi, yang nilainya berkisar antara $-0,25$ sampai $-0,5 .^{2}$

$\mathrm{Hu}$ dan Mao, ${ }^{21}$ menyatakan bahwa elastisitas harga biasanya lebih tinggi di negara berkembang dibanding elastisitas di negara maju. Alasannya adalah tingkat pendapatan penduduk di negara berkembang yang relatif kecil sehingga mereka lebih cepat bereaksi terhadap perubahan harga rokok. Pernyataan tersebut kurang cocok untuk Indonesia. Perokok Indonesia memiliki ketergantungan miopik sehingga ketika sedang menyedot rokok mereka tidak peduli akan dampak negatif masa depan baik terhadap aspek kesehatan maupun ekonomi. Disamping itu, studi ini juga menemukan variabel tingkat pendapatan, walau koefisiennya positif (lihat Tabel 5), secara statistik tidak berhubungan dengan konsumsi rokok.

Kecilnya elastisitas harga rokok bisa digunakan sebagai "amunisi" untuk menangkal mitos tentang dampak negatif kenaikan cukai rokok terhadap pendapatan negara. Mitos yang berkembang adalah "jika cukai rokok dinaikkan maka pendapatan negara turun karena jumlah orang yang merokok akan semakin sedikit". Kebijakan menaikkan cukai rokok tidak serta merta mengurangi pendapatan pemerintah. Hal ini bisa terjadi karena turunnya konsumsi rokok tidak akan sebanding dengan besaran kenaikan pajak. Hasil estimasi elastisitas studi ini menunjukkan bahwa kenaikan harga rokok sebesar $10 \%$ hanya menyebabkan turunnya konsumsi rokok (per harinya) 3,5\% (jangka pendek) dan $3,9 \%$ (jangka panjang). Pengalaman di sejumlah negara juga menunjukkan bahwa menaikkan pajak rokok, betapapun tingginya, tidak menyebabkan turunnya 
pendapatan pemerintah. Syukurlah karena Menteri Keuangan telah menaikan cukai rokok dari 37\% menjadi efektif 53\% mulai bulan Februari 2009.

Konsumen yang kecanduan rokok relatif lambat menanggapi kenaikan harga dan mereka akan tetap membeli, apalagi perokok memiliki sifat kecanduan miopik. Tidak heran jika pedagang rokok di Bali optimis kenikan cukai rokok per 1 Februari 2009 tidak akan mengurangi daya beli masyarakat. "Permintaan akan tetap tinggi terutama pangsa pasar kalangan remaja” ungkap mereka. Kalau ada perokok berhenti karena harga rokok naik (harapan kebijakan kesehatan), uang yang tadinya digunakan untuk membeli rokok akan digunakan untuk membeli barang yang menyehatkan.Tidak ada bukti empiris jika cukai rokok naik pendapatan pemerintah dari cukai akan turun. Jadi, mitos ini adalah salah besar.

\section{Kesimpulan}

Pemilihan penulis menjelaskan sejumlah kriteria untuk memilih metode tercocok dalam mengestimasi model spesifikasi dinamis. Peneliti menjajaki empat teknik ekonometrik untuk mengoreksi masalah seleksi bias serta mengakomodasi perilaku random-error. Aplikasi ekonometrik ini diterapkan pada data panel IFLS tahun 19932000. Teknik ekonometrik terbaik dipilih berdasarkan uji eksogenitas, heteroskedastisitas, serta sejumlah uji variabel instrumental yang terdiri atas uji korelasi, validitas dan ortogonalitas instrumen.

Hasil estimasi membuktikan bahwa rokok merupakan produk yang menyebabkan kecanduan. Namun, demikian hipotesis kecanduan rasional ditolak. Produsen rokok tampaknya berhasil menyajikan pesan tentang produk-produknya lebih menarik ketimbang pesan tentang bahaya merokok. Ini mencerminkan bahwa perokok Indonesia tidak rasional, mereka memiliki kecanduan miopik. Perhitungan nilai elastisitas menyimpulkan bahwa permintaan rokok sedikit lebih sensitif terhadap perubahan harga jangka panjang ketimbang perubahan harga jangka pendek.

\section{Saran}

Berdasarkan hasil temuan, disarankan agar promosi anti merokok dijadikan tujuan utama kebijakan nasional. Pelaksana kebijakan harus merancang ulang strategi kampanye anti merokok yang lebih agresif dan efektif. Pesan anti merokoknya juga harus menarik perhatian, tidak hanya dikemas dalam bentuk tulisan tetapi juga dalam bentuk gambar yang lebih kuat mengubah perilaku.

Pemerintah hendaknya terus menaikkan cukai rokok secara periodik sampai 57\% dari harga rokok sebagaimana diatur UU Cukai tahun 2007. Kebijakan ini akan mendorong sebagian perokok berhenti merokok dan mencegah orang lain untuk mulai merokok. Cukai yang tinggi juga akan mencegah sejumlah mantan perokok kembali merokok dan menurunkan besarnya konsumsi rokok bagi orang-orang yang masih merokok. Kebijakan menaikkan cukai rokok tidak akan mengurangi pendapatan negara, justru sebaliknya. Pemerintah diharapkan mulai menerapkan earmarked tax dengan mengalokasikan minimal 2\% dari harga rokok sebagai dana khusus untuk program promosi kesehatan.

Fatwa MUI tentang haramnya hukum merokok yang masih parsial hendaknya diperkuat pada masa yang akan datang dan disosialisasikan dengan intensif.

\section{Ucapan Terima Kasih}

Studi ini terlaksana atas dukungan dana dari Public Health Institute (PHI) sebagai koordinator Grant Research dari the National Institute of Health (NIH) Fogarty International Center project Tobacco Control Policy Analysis and Intervention Evaluation. Peneliti juga mengucapkan penghargaan kepada the RAND Corporation yang memberikan kesempatan untuk menggunakan data IFLS. Pendapat yang dilontarkan dalam tulisan ini adalah murni dari peneliti, tidak merepresentasikan penyandang dana-NIH- maupun the RAND Corporation. Segala bentuk kesalahan yang ada menjadi tanggung jawab penuh peneliti.

Artikel ini telah diterima untuk disajikan pada kegiatan "14th World Conference on Tobacco or Health" di Mumbai, India pada 18-12 Maret 2009. Artikel ini juga telah diajukan pada "The $7^{\text {th }}$ World Conference International Health Economics Association (iHEA)", di Beijing 17 Juni 2009. Draft awal tulisan ini pernah disajikan pada kegiatan "International Conference on Tobacco Control", yang diselenggarakan oleh Public Health Institute di Bali pada 13-15 Mei 2008. Terima kasih atas masukan yang diberikan oleh peserta konferensi (Prof Teh Wei-Hu, Prof Moo, Anita Lee Ph.D, Michael Ong Ph.D, Pujiyanto MKes, Ede Surya Dharmawan MPP, dll). Peneliti mengucapkan terima kasih kepada Hendratno Tuhiman atas kontribusinya dalam analisis data.

\section{Daftar Pustaka}

1. Baltagi BH. Econometric analysis of panel data. 3rd Edition. Chichester: Wiley; 2005.

2. Chaloupka FJ, Warner KE. The Economics of smoking. Handbooks of Health Economics. A.J.Culyer and J.P. Newhouse eds. North-Holland. 2000;1B.

3. Baltagi B, Griffin J. The econometrics of rational addiction: the case of cigarettes. Journal of Business and Economics Statistics. 2001;19:449454.

4. Grossman M, Chaloupka F J. The demand for cocaine by young adults: a rational addiction approach. Journal of Health Economics. 1998; 17:427-474

5. Olekalns N, Bardsley P. Rational addiction to caffeine: an analysis of cof- 
fee consumption. Journal of Political Economy. 1996;104(5):11001104.

6. Auld MC, Grootendorst P. An empirical analysis of milk addiction. Journal of Health Economics. 2004;23:1117-1133.

7. Adioetomo M, Djutaharta T, Hendratno. Cigarette consumption, taxation, and household income: Indonesia case study. HNP Discussion Paper. Economics of Tobacco Control Paper No. 26. Washington DC: The World Bank; 2005.

8. Djutaharta T. Aggregate analysis of the impact of cigarette tax rate increases on tobacco consumption and government revenue: the case of Indonesia. HNP Discussion Paper. Economics of Tobacco Control Paper No. 25. Washington DC: The World Bank; 2005.

9. Becker G, Murphy KM. A Theory of rational addiction. Journal of Political Economy. 1988;96(41):675-700.

10. Becker G, Grossman M, Murphy K. An empirical analysis of cigarette addiction. American Economic Review. 1994:396-418.

11. Windmeijer FAG, Santos-Silva JMC. Endogeneity in count data models: an application to demand for health care. Journal of Applied Econometrics. 1997;12: 281-294.

12. Jones AM, Labeaga JM. Individual heterogeneity and censoring in panel data estimates of tobacco expenditure. Journal of Applied Econometrics. 2003;18:157-177.

13. Pagan AR, Hall D. Diagnostic tests as residual analysis. Econometric Reviews. 1983;2:159-218.
14. Bound J, Jaeger DA, Baker RM. Problems with instrumental variables estimation when the correlation between the instruments and the endogeneous explanatory variable is weak. Journal of American Statistical Association. 1995;90:443-450.

15. Shea J. Instrumental relevance in multivariate linier models: A simple measure. Review of Economics and Statistics. 1997;79:348-352.

16. Baum CF, Schaffer ME, Stillman S. Instrumental variables and GMM: estimation and testing. Stata Journal. 2003;3:1-31.

17. Frankenberg E, Karoly L. The 1993 Indonesia Family Life Survey: overview and field report. DRU-1195/1-NICHD/AID. California, USA: The RAND Corporation; 1995.

18. Frankenberg E, Thomas D. The Indonesia Family Life Survey (IFLS): study design and results from waves 1 and 2. DRU-2238/1NIA/NICHD. California, USA: The RAND Corporation; 2001.

19. Strauss J. The Third Wave of the Indonesia Family Life Survey (IFLS3): overview and field report. WR144/1-NIA/NICHD. California, USA: The RAND Corporation; 2004.

20. Roodman D. How to do xtabond2: an introduction to difference and system GMM in Stata. Working Paper 103, Center for Global Development, Washington DC; 2006. Available from: http://www.cgdev.org/content/publications/detail/11619.

21. Hu T, Mao Z. Economics analysis of tobacco and options for tobacco control: China casa study. HNP Discussion Paper -Economics of Tobacco Control Paper No 3. Washington DC: The World Bank; 2002. 